\title{
CROSS-BORDER INVESTMENT, CONFLICT OF LAWS, AND THE PRIVATIZATION OF SECURITIES LAW
}

\author{
ROBERT W. HiLlmaN*
}

\section{INTRODUCTION}

As those familiar with Bernie Cornfeld's escapades know very well, transnational flows of investment capital are not new. ${ }^{1}$ Transnational investing, however, has reached a sufficient magnitude to justify viewing world capital markets as a whole, rather than a loose confederation of domestic enclaves. Today, investment advisers routinely counsel clients to diversify by including foreign equity and debt offerings in their portfolios, a recommendation that finds considerable support among academics. ${ }^{2}$ Investors heeding this advice will have little difficulty in internationalizing their investments through purchases of foreign securities, American Depositary Receipts ("ADRs"), or mutual funds with either a global orientation or an emphasis in a specific country or region. ${ }^{3}$

The proliferation of closed-end mutual funds listed on U.S. exchanges enables American investors to invest with a specificity previously impossible to achieve. The growth of these options vividly illustrates the internationalization of investment choices. Today, even an inexperienced investor may own, within minutes, shares in a multitude of mutual funds that invest in a specific country's stock market, such as the Asia Pacific, Austria, Brazil, Chile, Germany, Mexico, India, Irish, Italy, Jakarta Growth, Korea, Malaysia, Singapore, Thai, or Turkish Investment Funds, to name but a few.

The rapid acceleration of transnational investing is occurring in an environment in which emerging markets, and foreign interest in these

Copyright $\odot 1992$ by Robert W. Hillman

- Professor of Law, University of California, Davis.

My thanks to Patrick Borchers, James Cox, Friedrich Juenger, and William Reppy for their many helpful comments on an earlier draft of this article. Kit Gardner provided valuable research assistance.

1. See, for example, Charles Raw, Bruce Page \& Godfrey Hodgson, Do You Sincerely Want to be Rich? The Full Story of Bernard Cornfeld and IOS 150 (Viking Press, 1971).

2. See, for example, Alan Shapiro, Modern Corporate Finance 130 (1990) ("Prudent investors know that diversifying across industries leads to a lower level of risk for a given level of expected return. ... By diversifying across nations whose economic cycles are not perfectly in phase, investors should be able to reduce still further the variability of their returns.").

3. See generally Joseph A. Grundfest, Internationalization of the World's Securities Markets: Economic Causes and Regulatory Consequences, 4 J Fin Serv Res 349 (1990). 
markets, are exploding. ${ }^{4}$ A 1991 report of the International Finance Corporation ("IFC") identified thirty-three emerging stock markets. ${ }^{5}$ In the $1980 \mathrm{~s}$, the total capitalization of the twenty largest of these markets increased by a factor of seven, while the number of companies listed doubled. ${ }^{6}$ The capitalizations of the Korean and Taiwanese markets often exceed $\$ 100$ billion each. $^{7}$ To put this in perspective, a market capitalization of $\$ 100$ billion approximates the size of the Canadian market in 1980, and is considerably larger than the combined German and French markets at that time. In 1990, more than 1200 companies in the top twenty emerging markets raised over twenty-two billion dollars from stock offerings. ${ }^{8}$ Although much of the equity was raised from local sources of capital, the IFC expects the number of international offerings to rise substantially in the $1990 \mathrm{~s}^{9}$ In addition, although the IFC notes the improving regulatory environment in the markets, it rates investor protection in three of the twenty of the largest emerging markets as "poor,"10 with only six of the markets achieving a rating of "good." 11

The increasing link between developed markets and the likely development of emerging markets as major consumers of foreign capital will change the way we view securities regulation in the next decade. ${ }^{12}$ Although securities scholars have devoted considerable attention to the internationalization of securities markets, their primary focus has been on the developed markets of North America, Western Europe, and Japan. Much of this attention has been directed to the problem of "extraterritorial" assertion of jurisdiction-the application of domestic securities law to transactions with significant foreign elements. ${ }^{13}$ Even when limited to conflicts between the regulatory laws of countries with developed markets and significant

4. See The Surprising Emergence of Distant Shares, The Economist 93 (Nov 16, 1991) (describing the rapid development of interest in emerging markets, and commenting that scarcely a month goes by without a British or American investment manager launching a fund to take a slice of these markets).

5. See International Finance Corp., Emerging Stock Markets Factbook 1991 vii (International Financial Corporation, 1991).

6. Id at 2 .

7. Id at 51. Market volatility makes comparisons difficult. The capitalization of the Taiwan market fell from $\$ 237$ billion to $\$ 100$ billion between 1989 and 1990 , while capitalization of the Korean market dropped from $\$ 140$ billion to $\$ 110$ billion over the same period. Id.

8. Id at 2.

9. Id at 5 .

10. These are Taiwan, Greece, and Turkey. Id at 68.

11. These are Brazil, Chile, Mexico, India, Korea, and Malaysia. Argentina, Columbia, Venezuela, Indonesia, Pakistan, the Philippines, Thailand, Jordan, Nigeria, Portugal, and Zimbabwe were rated "good, of internationally acceptable quality." Id.

12. Third world countries were major sources of investment capital in the largest international investment scam we have seen to date. It has been estimated that $40 \%$ of the $\$ 500$ million 1 OS held under management in 1966 came from developing countries. See Raw, Page \& Hodgson, Do You Sincerely Want to be Rich? 150 (cited in note 1).

13. The "extraterritorial application of law" terminology is misleading in that it implies that law is applied beyond the boundaries of the state. Although some commentators refuse for this reason to speak of extraterritorial assertion of jurisdiction, the expression appears with regularity in both the case law and the literature. Since the terminology seems to have caused little confusion, I will use it in this article. 
commonalities in their securities "cultures," the problem is intractable because of the inherent limitations in domestic regimes unilaterally regulating transnational flows of investment capital. ${ }^{14}$

At the regulatory level, some progress has been made in adapting the instruments of domestic enforcement to the realities of international finance. However, the world continues to have only national regulatory regimes, which are poorly equipped to regulate cross-border investments. In the absence of multilateral agreements or a supranational regime for regulating transborder capital flows, it will be the task of courts to develop much of the law applicable to transnational securities transactions. In performing this function, U.S. courts will, as they have done in the past, seek to determine congressional "intent," but since that intent is largely impossible to discern, ${ }^{15}$ they will write their opinions on tablets that are for all practical purposes blank.

This article explores the use of domestic law to redress cross-border investment fraud. It also considers the use of foreign law for the same purpose. To date, courts and commentators have regarded securities law as "public" law, and from that premise concluded that the matter is one of defining the appropriate "reach" of U.S. securities law. Generally, they speak of defining the limits on the extraterritorial application of domestic law by reference to limitations supposedly imposed by international law on a nation's "jurisdiction to prescribe" law. To this end the Restatement (Third) of the Foreign Relations Law of the United States seeks to establish the boundaries defining the reach of domestic securities law. ${ }^{16}$ By so treating the issue, a court will either dismiss a case for lack of jurisdiction to prescribe law, or find that such jurisdiction exists and apply domestic law.

In contrast, a quite distinct alternative is to consider choice of law and the use of foreign law to resolve disputes involving investors. Permitting a choice between domestic and foreign law securities does, however, require reassessment of whether securities law is, in its entirety, public law, and therefore not amenable to choice of law, a task undertaken by this article.

\section{II}

\section{Extraterritoriality: The American Cases in Brief}

In the United States, judicial treatment of the limits of extraterritorial application of domestic law is developed most fully in a line of antitrust cases, all of which treat extraterritoriality as an issue of jurisdiction rather than choice of law. Originally, courts adopted a very restrictive view of the extraterritorial application of antitrust law. In American Banana Company $v$.

14. Defining the extraterritorial scope of legislation, of course, is a problem not unique to the securities and antitrust cases. See, for example, EEOC v Arabian American Oil Co., 111 US 1227 (1991) (Title VII does not apply extraterritorially to regulate the employment practices of U.S. firms employing U.S. citizens abroad.).

15. But see Margaret V. Sachs, The International Reach of Rule 10b-5: The Myth of Congressional Silence, 28 Colum J Transnatl L 677, 681 (1990) (arguing the securities markets of the 1920s were highly internationalized and Congress was well aware of this fact).

16. Restatement (Third) of Foreign Relations Law \$ 416 (ALI, 1987). 
United Fruit Company, ${ }^{17}$ the plaintiff, a U.S. citizen, sought treble damages from another American for inducing the Costa Rican government to seize the plaintiff's banana plantation, which had the not unexpected effect of making it impossible for the plantation to export bananas to the United States. Concluding that the legality of conduct must be determined solely by reference to the jurisdiction where it occurred, Justice Holmes, writing for the majority, observed:

It is obvious that, however stated, the plaintiff's case depends on several rather startling propositions. In the first place, the acts causing the damage were done, so far as appears, outside the jurisdiction of the United States and within that of other states. It is surprising to hear it argued that they were governed by the act of Congress. ${ }^{18}$

Holmes' reaction is itself surprising. At least as it pertains to crimes, the objective territorial principle - that is, jurisdiction based on acts outside the state that have effects within the state - had been recognized for at least sixty years prior to American Banana. A particularly interesting example is People v. Adams, ${ }^{19}$ an 1846 New York decision involving extraterritorial issues hauntingly similar to those raised by modern transnational securities fraud cases. There, the defendant was accused of making false representations through an innocent agent to procure funds from a New York firm. The New York court had little difficulty in claiming jurisdiction over the defendant, even though he was never in New York and perpetrated his crime from Ohio:

This in no sense affirms or implies an extension of our laws beyond the territorial limits of the state. The defendant may have violated the law of Ohio by what he did there, but with that we have no concern. . . True, the defendant was not personally within this state, but he was here in purpose and design, and acted by his authorized agents. ... This necessarily gives [New York courts] jurisdiction over the criminal. ${ }^{20}$

Similarly, the Georgia Supreme Court offered one of the more imaginative explanations of how a crime may be committed in a state even though the perpetrator was never within the state's boundaries. Simpson v. State ${ }^{21}$ involved the proverbial shot across the border. In upholding Georgia's right to prosecute the crime, the court explained:

So, if a man in the State of South Carolina criminally fires a ball into the State of Georgia, the law regards him as accompanying the ball, and as being represented by it, up to the point where it strikes. . . [ [T]he act of the accused did take effect in this State. He started across the river with his leaden messenger, and was operating it up to the moment when it ceased to move, and was therefore, in a legal sense, after the ball crossed the State line up to the moment it stopped, in Georgia. ${ }^{22}$

Although the Georgia court's imagery would surely be tested in case involving financial fraud (imagine the decidedly safer and more leisurely journey across the border on a prospectus), this case and others like it establish that effectsbased jurisdiction was a part of American law at the time of American Banana.

17. 213 US 347 (1909).

18. Id at 355 .

19. 3 Demo (NY) 190 (1846).

20. Id at 210 .

21. $92 \mathrm{Ga} 41$ (1893).

22. Id at 43-46. 
In American Banana, Holmes, of course, was not dealing with a criminal prosecution for fraud or a shot across the border. His opinion in Strassheim $v$. Daily, ${ }^{23}$ decided only two years after American Banana, suggests that he may have distinguished between a traditional crime and a violation of economic regulatory laws having a more precise focus than fraud. There, Holmes had little difficulty concluding that Michigan could prosecute an Illinois resident for obtaining money by false pretenses even though the individual charged had not set foot in Michigan until after the fraud was completed. He reasoned, "Acts done outside the jurisdiction, but intended to produce and producing detrimental effects within it, justify a State in punishing the cause of the harm as if he had been present at the effect, if the State should succeed in getting him within its power."'24

In United States $v$. Aluminum Company of America, ${ }^{25}$ Learned Hand firmly established effects as a basis for the application of domestic antitrust law. ${ }^{26}$ It was "settled law," in Hand's view, "that any state may impose liabilities, even upon persons not within its allegiance, for conduct outside its borders that has consequences within its borders which the state reprehends; and these liabilities other states will ordinarily recognize."'27 Although Hand cited only weak authority (including Strassheim) for his conclusion as to settled law, $A L C O A$ provided the support needed for an aggressive application of U.S. antitrust laws on the basis of effects in the United States.

Foreign response to effects as a basis of jurisdiction in U.S. antitrust cases has been, as is well known, unabashedly hostile, ${ }^{28}$ though effects-based jurisdiction is hardly unique to the United States. In response to the perceived harshness of utilizing effects as a basis of jurisdiction, Timberlane Lumber Co. $v$. Bank of America ${ }^{29}$ introduced a jurisdictional rule of reason centering on a balancing test designed, the court believed, to reflect the importance of other nations' interests. ${ }^{30}$ Although Timberlane suggested that a court may have jurisdiction but, for reasons of comity, decline to exercise it, ${ }^{31}$ Mannington Mills, Inc. $v$. Congoleum Corp. ${ }^{32}$ held that balancing is appropriate to

23. 221 US 280 (1911).

24. Id at 285. See also Lamar $v$ United States, 240 US 60, 65-66 (1916) (Holmes opinion in criminal prosecution for impersonating a government officer concluding, "[ $t$ ]he personation was by telephone to a person in New York (Southern District) and it might be found that the speaker also was in the Southern District; but if not, at all events the personation took effect there.").

25. 148 F2d 416 (2d Cir, 1945) ("ALCOA").

26. Although $A L C O A$ is generally credited with establishing the effects test, the analysis was used much earlier in a successful challenge of shipping conferences. See United States $v$ HamburgAmerikanische Packet-Fahrt-Actien-Gesellschaft, 200 F 806 (Cir Ct SD NY 1911). See generally Andreas F. Lowenfeld, Public Law in the International Arena: Conflict of Laws, International Law, and Some Suggestions for their Interaction, 163 Recueil des Cours 313, 373-76 (1979).

27. $A L C O A, 148 \mathrm{~F} 2 \mathrm{~d}$ at 443.

28. See, for example, P.C.F. Pettit \& C.J.D. Styles, The International Response to the Extraterritorial Application of United States Antitrust Laws, 37 Bus L. 697 (1982).

29. 549 F2d 597 (9th Cir 1976).

30. Id at 611-12.

31. Id at 612 .

32. 595 F2d 1287 (3d Cir 1979). 
determine whether jurisdiction vel non exists. ${ }^{33}$ A few courts have followed the leads of Timberlane and Mannington Mills, although the balancing they have done generally results in the conclusion that exercise of jurisdiction is appropriate, ${ }^{34}$ a result that should not surprise anyone familiar with conflicts cases revealing a similar disposition. Other courts categorically reject balancing and adhere to $A L C O A$ 's test for jurisdiction. ${ }^{35}$

\section{III}

\section{Effects, Balancing, and Public International Law}

Significantly, the Third Restatement of Foreign Relations Law ("Third Restatement") accepts the jurisdictional rule of reason of Timberlane and Mannington Mills and incorporates a balancing test designed to determine the existence of jurisdiction to prescribe law. ${ }^{36}$ This approach, the Restatement informs us, is dictated by public international law. ${ }^{37}$ In fact, international law is far from clear on the point.

The reason for the uncertainty lies in varying assumptions concerning what international law is. On one side are those who believe that international law empowers states to prescribe law. "Jurisdiction," a proponent of this view has argued, "involves a State's right to exercise certain of its powers." 38 Those of this inclination must surely enjoy use of the phrase "jurisdiction to prescribe," which suggests the existence of some supranational body that parcels out law-making competence to territorial units called states. On the other side are those who take a more restrictive or ambivalent view of international law and thus can say "[i]nternational law sets little or no limitation on the jurisdiction which a particular state may arrogate to itself." 39

A second and related aspect of the controversy is disagreement over whether international law serves to confer power on states or whether it operates to restrict the exercise of power by states. If international law is enabling and confers power, the inquiry becomes one of evaluating whether by treaty or by custom the international community has sanctioned the exercise of jurisdiction under similar circumstances. If, on the other hand,

33. Id at 1291-93, 1297-98.

34. See generally Alan D. Neale \& Mel L. Stephens, International Business and National Jurisdiction 76 (Clarendon Press, 1988) ("Indeed, it should not be forgotten that the Circuit Court judgments in Timberlane and Mannington Mills were both reversals of lower court decisions to dismiss cases for lack of jurisdiction. These cases stand as a warning therefore that the introduction of the balancing process was not in practice to mark any great retreat from extraterritorial enforcement of antitrust, especially with regard to foreign defendants."); Joseph P. Griffin, Possible Resolutions of International Disprutes over Enforcement of US Antitrust Laws, 18 Stan J Intl L 279 (1982) (concluding that courts invariably assert jurisdiction after balancing interests).

35. See, for example, Laker Airways, Ltd. v Sabena, Belgian World Airlines, 731 F2d 909, 923 (DC Cir 1984).

36. Restatement (Third) of Foreign Relations Law $\$ 403$.

37. Id at $\S 403$, comment a.

38. Fritz A. Mann, Studies in International Law 3 (Clarendon, 1973) (emphasis in original).

39. Joseph G. Starke, Introduction to International Law 193 (Butterworths, 9th ed 1984) (emphasis added). 
international law operates in a restrictive fashion, the inquiry shifts to determining whether, by treaty or by custom, the international community has deemed the exercise of jurisdiction improper. The framing of the inquiry thus controls the conclusions to be reached.

A third aspect of the controversy over whether and how international law relates to jurisdiction to prescribe law is the disagreement over the positive or normative nature of international law. The early scholars of modern international law placed great importance on natural law as a source of the law of nations. More recently, international law has come to rest on a positivist, rule-oriented foundation. The "sterile positivism" 40 of international law, however, is under unrelenting assault by academics who look to the rule of law as a means of bringing order to what they regard as a chaotic world. ${ }^{41}$ Normative-based arguments concerning international law do have a certain seductive appeal, but there is little evidence that states are prepared to abandon their positivist leanings in favor of an approach finding law in sources other than custom and treaties. True, the normative approach has influenced the development of international law in certain important and defined areas, the most notable of which is probably human rights. On the whole, however, states are likely to continue to view international law as grounded in custom and treaty, while disavowing a more threatening regime that regulates on the basis of what state practices ought to be.

It is strange that there are so few decisions of international tribunals on jurisdiction to prescribe and international law. The few that do exist, however, either support or do not undermine the application of domestic law based on effects, and certainly do not embrace the balancing approach required by the Restatement. The famous (infamous to some) S.S. Lotus case is one example. ${ }^{42}$ More recent developments in the European Community further undermine the notion that international law mandates balancing or a jurisdictional rule of reason. Since at least 1964, the Commission of the

40. Phillip R. Trimble, International Law, World Order, and Critical Legal Studies, 42 Stan L Rev 811 , $819(1990)$.

41. See authorities cited in id at $813 \mathrm{nl6}$. As one commentator put it,

[t]he rule-oriented approaches tend to view international law dogmatically as a static body of auto-operational rules-rules that are given and self-contained and operate automatically. .

The underlying assumption of the rule-oriented approaches is that law is 'rules' and nothing more. But law is more than this. . . International law is a continuing process of authoritative decision and cannot be adequately described by mere reference to the derivations from past decisions that are termed rules. Rules are not self-applicatory and do not change by themselves. Rules are made and applied by human beings. The task of applying law is not merely to discover the correct rules but to make choices, to make decisions.

Lung-chu Chen, An Introduction to Contemporary International Law 11-12 (Yale U Press, 1989).

42. The Case of the S.S. Lotus, Pub PCIJ (1927), Series A, No 10. The case was decided by the Permanent Court of International Justice ("PCIJ") in 1927. The dispute arose out of the collision of Turkish and French vessels on the high seas and the subsequent prosecution of a French officer by Turkey. France asserted that international law is enabling, and, therefore, the burden was on Turkey to identify a principle of international law that justified its prosecution. Turkey responded, not surprisingly, with the argument that international law is restrictive rather than enabling and, 
European Communities has asserted jurisdiction under articles eighty-five and eighty-six of the EEC Treaty, which relate to competition, on the basis of the effects doctrine.43 In 1989, the European Court of Justice reviewed the Commission's application of the effects doctrine in the Wood Pulp cases. ${ }^{44}$ In his advisory opinion to the Court, the Advocate General suggested that "consideration of the location of the effects as the basis of a State's jurisdiction is in conformity with the rules of international law." 45 As to the balancing tests of Timberlane and the Third Restatement, and as to his recommendation to the Court, the Advocate General opined:

In practice, therefore, it would not appear that the balancing of interests in accordance with the criteria formulated in Timberlane Lumber and Mannington Mills has made it possible to elicit a jurisdiction rule of reason. With one exception-a United States writer has pointed out-no court has refused to exercise its jurisdiction as a result of the analysis put forward in those judgments. . . . Consequently, the distinction between the existence and the exercise of jurisdiction, on the one hand, and, on the other, the recognition of a discretion to refrain from exercising existing jurisdiction constitute a misleading approach that should not be followed. . . .

[T] here is no rule in international law which is capable of being relied upon against the criterion of the direct, substantial and foreseeable effect. Nor does the concept of international comity, in view of its uncertain scope, militate against that criterion either.

In the absence of any such prohibitive rule and in light of widespread State practice, I would therefore propose that in view of its appropriateness to the field of competition, it be adopted as a criterion for the jurisdiction of the Community. ${ }^{46}$

accordingly, it was free to exercise jurisdiction so long as its activity did not conflict with an established principle of international law, of which there was none.

By finding that the Turkish view "seems to be in conformity with ... international law," id at 18 , the PCIJ dealt a serious blow to those who view international law as enabling. The divided court went on, in dicta, to offer some comments that continue to infuriate opponents of jurisdiction based on effects. After noting that jurisdiction is territorial and "cannot be exercised by a State outside its territory," the Court outlined a broad basis for the extraterritorial application of law:

Far from laying down a general prohibition to the effect that States may not extend the application of their laws and the jurisdiction of their courts to persons, property and acts outside their territory, [international law] leaves them in this respect a wide measure of discretion which is only limited in certain cases by prohibitive rules; as regards other cases, every state remains free to adopt the principles which it regards as best and most suitable. Id at 18-19.

43. Case 195/11 Re Aniline Dyes Cartel (the Dyestuffs case), [1969] 8 CMLR D23 (1969), decided nearly twenty years ago, has proven particularly important in this regard. The jurisdiction of the Commission was subsequently challenged on appeal to the European Court of Justice. The Advocate General concluded that domestic, international, and Community law permit the assertion of jurisdiction based upon effects, subject to certain limitations. Cases 48, 49,51-57/69, ICI and Others $v$ E.C. Commission, [1972] 11 CMLR 557, 600-07 (1972). Specifically, the effects must be direct and immediate restrictions on the market, must be reasonably foreseeable, and must constitute elements of the infringement. Id at 603-07. The Court, however, avoided either endorsing or rejecting effects as a justification for applying law by upholding the Commission's decision as to certain of the parties on the ground they had acted in the EEC through their subsidiaries (the theory of enterprise entity). Id at 628-29. Nevertheless, in later cases the Commission maintained its position that jurisdiction may be based on effects within the Community. See generally Christopher S. Kerse, EEC Antitrust Procedure $\$ \S 8.03-8.05$ at 38-39 (European Law Centre, 1988).

44. Cases 89, 104, 114, 116-17, 125-29/85, Re Wood Pulp Cartel: A Ahlström Oy v E.C. Commission (“Wood Pulp"), [1988] 4 CMLR 901 (1988).

45. Id at 923.

46. Id at $928,932$. 
The Court did not follow the recommendation of the Advocate General that it adopt an effects test as a basis of jurisdiction, but it also did not expressly reject the use of such a test. Instead, it accepted the suggestion of the United Kingdom that jurisdiction was properly based on the territorial principle, noting that the "decisive factor" was the place where the unlawful agreement is implemented:47 "The producers in this case implemented their pricing agreement within the Common Market. It is immaterial in that respect whether or not they had recourse to subsidiaries, agents, sub-agents, or branches within the Community in order to make their contacts with purchasers within the Community." 48

Although the place of implementation analysis of the Court lacks precision, the Court directly undermined the Third Restatement's endorsement of balancing in international law by declining to adopt a balancing test when it so clearly had an opportunity to do so. At the same time, the Court's disinclination to follow the recommendation of the Advocate General and determine jurisdiction on the basis of substantial and foreseeable effects calls into question the validity of the effects test under international law. The degree to which a place of implementation analysis differs in practice from an effects test remains to be seen, however.

\section{IV}

\section{The Question of Choice: Of Public International Law and}

\section{Conflict of Laws}

The premise that the limits of a nation's capacity to regulate economic matters is dictated by public international law frames the issue as one of jurisdiction rather than choice of law, which is the province of conflict of laws. Although some attempts have been made to unify the conflicts and public international fields, ${ }^{49}$ a rather sharp division exists between the disciplines. This is reflected both in the scholarship and in the fact that few scholars are active in both conflict of laws and public international law. ${ }^{50}$

Whether a matter is the subject of conflicts law or public international law, however, is a matter of some importance. The two fields share some

47. Id at 941 .

48. Id. Significantly, the Court rejected the argument of the U.S. companies that the Community's exercise of jurisdiction should be subject to a balancing test because the companies' activities were lawful under U.S. law. Without expressing an opinion on the requirements of international law, it disposed of the issue by noting that (1) U.S. law permits, but does not require, the formation of export cartels, and (2) U.S. authorities did not object to the Community's assertion of jurisdiction in this case. Id at 942 . Finally, the Court dismissed the argument that comity militates against jurisdiction with the terse comment that "it suffices to observe that it amounts to calling into question the Community's jurisdiction to apply its competition rules to conduct such as that found to exist in this case and that, as such, that argument has already been rejected." Id.

49. See, for example, Lowenfeld, 163 Recueil des Cours at 321 (cited in note 26).

50. The AALS Directory of Law Teachers reveals that out of 269 active teachers of conflicts and 314 active teachers of international law, only 33 teach both subjects. Viewing the two groups as a whole, the overlap is less than six percent. Association of American Law Schools, The AALS Directory of Law Teachers 1991-92 995-98, 1061-65 (West \& Foundation Press, 1991). 
methodological underpinnings, but the theories underlying conflicts and public international law are often quite different. Moreover, the essential problem addressed by conflicts is the choice of law. ${ }^{51}$ Conflicts inquiries, in other words, are directed to whether the forum will apply the law of jurisdiction $A$ or jurisdiction $B$ (or the law of third, fourth or fifth jurisdictions in more complex cases). As traditionally perceived, public international law regulates sovereigns, not individuals. Accordingly, public international law does not answer the question of whether the law of one jurisdiction or another will be invoked, but rather whether the forum is somehow entitled to apply its law to regulate conduct having significant foreign components.

\section{A. Economic Regulation as Public Law}

A widely accepted dividing line places disputes between nations within the public international law sphere, and disputes between individuals within the private law domain of conflicts. ${ }^{52}$ While simple, this distinction denies reality by ignoring the growing number of cases falling in the gap between the two. ${ }^{53}$ In particular, economic regulation through antitrust and securities laws necessarily leads to enforcement of public law against foreign private parties. When enforcement takes the form of a criminal prosecution, choice of law is not an issue because courts will not, as a rule, entertain a prosecution based upon a violation of the criminal law of another jurisdiction. But what of private actions grounded in violations of public law? Here again, the reluctance to invoke foreign public law is manifested in reasoning that private litigants are, in effect, acting as surrogates for enforcement agencies. ${ }^{54}$

Theory notwithstanding, a number of cases involving the application of antitrust and securities laws reveal that courts do look to conflicts law for guidance to determine the scope of domestic law. In $A L C O A$, for example, the court defined the issue as a problem of divining congressional intent, adding that "we are not to read general words, such as those in this Act, without regard to the limitations customarily observed by nations upon the exercise of their powers; limitations which generally correspond to those fixed by 'Conflict of Laws.'",55

51. See Th. M. de Boer, Beyond Lex Loci Delicti: Conflicts Methodology and Multistate Torts in American Case Law 7-373 (Kluwer, 1987) ("[C]hoice of law is premised on the forum's willingness to accept a foreign rule of decision as a potential substitute for its own. Without this principle, no choice of law system can exist.").

52. See, for example, Harold G. Maier, Extraterritorial Junisdiction at a Crossroads: An Intersection between Public and Private International Law, 76 Am J Intl L 280 (1982) (describing and criticizing the distinction).

53. See, for example, Lowenfeld, 163 Recueil des cours at $321-22$ (cited in note 26).

54. See, for example, Neale \& Stephens, International Business and National Jurisdiction at 10 (cited in note 34) ("It is true that U.S. antitrust law provides for civil actions between private parties. . . But as this feature of antitrust law derives from the theory that private plaintiffs should be encouraged to act as supernumerary attorneys general for the more effective enforcement of the law, and as they are offered the prospect of treble damages as an incentive to do so, we regard such litigation for practical purposes as within the ambit of penal jurisdiction."').

55. 148 F2d at 443 . 
In establishing an effects test without regard to comity, $A L C O A$ followed the lead of the First Restatement of Conficts, which reflected strong territorialist leanings and no sensitivity to comity. Timberlane endorsed conflict of laws as the proper approach to resolve extraterritorial issues, and offered a test reflecting the approach of the Second Restatement of Conflicts. ${ }^{56}$ Both cases, however, utilized conflicts law not to determine which law would be applied but rather to determine whether domestic law would be invoked. In this way, ALCOA and Timberlane adhered to the traditional view that economic regulation cases pose issues of jurisdiction to prescribe law but not choice of law.

$A L C O A$ and Timberlane are not alone in their teasing references to the relevance of conflicts in defining the reach of economic regulation. In 1979, Andreas Lowenfeld published an engaging article challenging traditional distinctions between conflicts and public international law and urging the use of conflicts law in cases involving the public law of foreign states. ${ }^{57}$ The article was important because Lowenfeld was later to have a major influence on the Third Restatement of Foreign Relations Law. Like ALCOA and Timberlane, Lowenfeld argued the importance of conflicts, but did not take the final step, which would have domestic courts apply foreign public law. Accordingly, a conflicts analysis becomes relevant only to the issue of jurisdiction to prescribe law. If jurisdiction does not exist, the case is dismissed. The option of choosing foreign or domestic law is denied when economic regulatory law is at issue because tradition assigns such law to the province of public law.

\section{B. The Public/Private Distinction Revisited}

Adherence to the public/private law distinction explains why the Third Restatement of Foreign Relations, rather than the Second Restatement of Conflicts, covers extraterritorial issues arising in securities and antitrust cases, and effectively negates the use of a choice of law analysis. Yet the oft-repeated point that conflicts is concerned with "private" rather than "public" law is more harmful than illuminating, ${ }^{58}$ particularly when used to eliminate choiceof-law considerations in such supposedly public law areas as securities regulation. As becomes apparent when the revered concept of state "interests" is explored, labels widely used in the conflicts field are poor substitutes for analysis.

In the United States, the aversion to judicial enforcement of foreign penal laws is traceable to The Antelope, ${ }^{59}$ where, citing only the "law of nations," Chief Justice Marshall observed that " $t]$ he Courts of no country execute the

56. 549 F2d at 609-10; see also notes 29-31 and accompanying text.

57. See Lowenfeld, 163 Recueil des Cours at 321 (cited in note 26).

58. On the distinction, see generally Roger Cramton, David P. Currie \& Herma Hill Kay, Conflict of Laws 126-37 (West, 1981); Robert A. Leflar, Extrastate Enforcement of Penal and Governmental Claims, 46 Harv L Rev 193 (1932); Monrad G. Paulsen \& Michael I. Sovern, Public Policy in the Conflict of Laws, 56 Colum L Rev 969 (1956).

59. 23 US (10 Wheat) 66 (1825) 
penal laws of another."60 That statement undoubtedly remains true as to matters of a truly criminal character. But what of claims based upon statutes not clearly penal in character?

In Loucks v. Standard Oil Co. ${ }^{61}$ Judge Cardozo offered one of the more insightful discussions of this problem. The action, brought to recover damages for wrongful death, presented the issue of whether New York could enforce the wrongful death statute of Massachusetts, where the death occurred. The defendant invoked The Antelope and argued New York should not apply a Massachusetts penal statute. Although he recognized the statute's criminal law heritage, Cardozo had no difficulty in applying the Massachusetts law:

Through all this legislation there runs a common purpose. . . It is penal in one element and one only; the damages are punitive. . . . But the punishment of the wrongdoer is not designed as atonement for a crime; it is solace to the individual who has suffered a private wrong. ... .

To exclude all penal actions would be to wipe out the distinction between public justice and the remedies of private law. ${ }^{62}$

Similarly, the Second Restatement of Conficts states that "[n]o action will be entertained on a foreign penal cause of action," but adds in a comment that the restriction is to be applied narrowly and does not extend to "actions brought by a private person or public body to recover compensation for a loss."63 And the public law bar presented no obstacle to the California Supreme Court, which recently refused to enforce a produce marketing contract between a California corporation and a California resident on the ground that the contract pertained to Mexican farming operations, and the Mexican constitution, at the time, made ownership of the land by foreigners illegal. ${ }^{64}$

The public/private distinction is nothing more than a generalization, the meaning of which may be ascertained only after a consideration of the character of the domestic law involved and the context in which it is to be enforced. The next section evaluates the perceived wisdom that securities law is public and therefore beyond the province of choice of law.

\section{The Privatization of Securities Law}

The tendency of courts and commentators categorically to assign regulatory laws to the public sphere and thereby deny choice-of-law alternatives is curious. What does it mean to say that law is regulatory, and therefore public, such that a court is compelled either to apply domestic law

60. Id at $122-23$.

61. 224 NY 99 (1918).

62. Id at 105,112 .

63. Restatement (Second) of Conflict of Laws $\S 89$, comment a (1971). See also id $\S 90$ ("No action will be entertained on a foreign cause of action which is contrary to the strong public policy of the forum." (emphasis added)).

64. See Wong $v$ Tenneco, Inc., 39 Cal 3d 126 (1985). 
or to dismiss the case, particularly one pursued as a private cause of action, on jurisdictional grounds?65 Does the same public sphere reasoning necessarily hold in transnational regulatory cases for the reason, articulated by one commentator, that "[a] government always has a direct interest in the outcome of a regulatory case even when [its] viewpoint is represented by a citizen-prosecutor seeking private recovery. Thus, transnational regulatory cases always decide the correlative rights of governments." 66 At least as applied to securities regulation, this type of thinking does real damage by ignoring the eclectic nature of contemporary securities regulation. Securities law is neither wholly private nor wholly public, but is instead at times public, at times private, and at times a curious blend of the two. Law that at first glance appears public may, upon closer examination, reveal its true character as private law.

Certain aspects of securities regulation have strong public law overtones. Regulation of insider trading, regulation of broker-dealers, prohibitions against bribing foreign government officials, mandatory reporting requirements, and proxy solicitation rules are examples of the many aspects of securities law driven by public interest concerns-protection of markets and the investing public-and therefore may plausibly be regarded as public law. Whether these types of regulation are necessarily beyond the province of choice of law is an interesting and unexplored issue, but one which must await treatment at another time. This article instead focuses on the point that some important aspects of securities regulation strongly resemble types of private law that are traditionally handled under conflicts analysis, where choice of law is very much before the court.

Consider the common pattern of regulating a public stock offering. The Securities Act of 1933 requires that issuers precede such an offering with a filed disclosure document, the registration statement, which provides information about the issuer, the securities, the use of proceeds, and the like. ${ }^{67} \mathrm{~A}$ number of foreign states, including the United Kingdom, ${ }^{68}$ Mexico, ${ }^{69}$ Hong Kong, ${ }^{70}$ Canada, ${ }^{71}$ Australia, ${ }^{72}$ and

65. This discussion focuses on private litigation rather than administrative enforcement actions or criminal prosecutions.

66. Maier, $76 \mathrm{Am} \mathrm{J} \mathrm{Intl} \mathrm{L} \mathrm{at} 289$ (cited in note 52). See also Robert A. Sedler, Professor Juenger's Challenge to the Interest Analysis Approach to Choice-of-Law, 23 UC Davis L Rev 865, 877 (1990) ("[T]he United States clearly has a governmental interest in implementing the policy reflected in the antitrust and securities laws. This interest is implicated not only when the United States is acting to enforce these laws, but also when these laws are invoked by an injured party in a private action brought against an alleged violator.").

67. Securities Act of 1933, 15 USC $\S \S 77$ et seq (1988) (“Securities Act”).

68. See Norman S. Poser, International Securities Regulation $\$ 3.8$ (Little Brown, 1991).

69. Javier Lizardi Calderon \& Samuel Wolff, Mexico, in Harold S. Bloomenthal, ed, International Capital Markets and Securities Regulation § 4.A.08 (Clark Boardman, 1990) ("International Capital Markets").

70. See Terrance M. Rogers, Hong Kong, in Bloomenthal, International Capital Markets at $\$ 12.05$ (cited in note 69).

71. See Jeff G. Cowan, Canada, in Bloomenthal, International Capital Markets at $\S 4.04$ (cited in note 69 ). 
Japan $^{73}$ follow (more or less) the same approach, as does the Prospectuis Directive of the European Community. ${ }^{74}$ Although the content of the disclosure document, liability for misrepresentations or omissions of material information, the roles and competence of regulatory agencies, accounting standards, and the existence of private causes of action are among the details of regulation that vary from state to state, the principle that mandated disclosures are a necessary component of public offerings, is inherent in many securities law regimes. Mandating disclosures at the time of a public offering is justified by the economies of scale in the production and verification of information that make the issuers of securities the low cost providers of information. ${ }^{75}$ Importantly, the disclosures benefit not only the purchasers in the offerings, but also the markets in which the securities are traded by insuring that participants in secondary trading markets are informed by the information provided in the registration statement. ${ }^{76}$ For these reasons, the registration provisions of the Securities Act benefit investors, traders, and, more generally, markets. For present purposes, these provisions may thus be regarded as public law.

The need for mandated disclosures decreases when securities are sold to a small group of investors and will not be resold, at least for a time, into secondary markets. When investors deal at arms length with the issuer and have the opportunity, incentive, and ability to ferret out information on their own, the disparity between information production and verification costs that exist in a public offering disappears, or at least narrows substantially. ${ }^{77}$ Accordingly, the Securities Act exempts transactions not involving "public offerings" from registration requirements via an exemption commonly referred to as the "private placement exemption." 78 Other nations typically relax or eliminate disclosure requirements for private placements, although

72. See J. P. Hambrook, Australia, in Bloomenthal, International Capital Markets at $\$ 10.04$ (cited in note 69). 69).

73. See Misao Tatsuta, Japan, in Bloomenthal, International Capital Markets at $\$ 11$ (cited in note

74. See generally Poser, International Securities Regulation at $\$ 4.1 .2$ (cited in note 68).

75. The desirability of mandating disclosures is a matter of some controversy. See, for example, Frank H. Easterbrook \& Daniel R. Fischel, Mandatory Disclosure and the Protection of Investors, $70 \mathrm{Va} \mathrm{L}$ Rev 669 (1984) (critical of mandating disclosures); John C. Coffee, Jr., Market Failure and the Economic Case for a Mandatory Disclosure System, 70 Va L Rev 717 (1984) (supporting mandating disclosures).

76. See James D. Cox, Robert W. Hillman \& Donald C. Langevoort, Securities Regulation 45-46, 215 (Little, Brown, 1991).

77. See, for example, William J. Carney, Defining a Security: The Addition of a Market-Oriented Contextual Approach to Investment Contract Analysis, 33 Emory L J 311, 356 (1984) ("One-on-one negotiations provide no scale advantages for either party in the transaction.").

78. See $\S 4(2)$ Securities Act. The private placement market is large and growing, and it would be wrong to assume that private placements represent investments too small to find support in the public markets. Although some such placements are small, others are large. In a single week, the Financial Times reported 10 significant transnational investments, ranging from a Group Axa's agreement to purchase a one billion dollar stake in Equitable Life to Pepsico's purchase of an interest in a Polish chocolate operation. See Brian Bollen, International Cross Border Deals, Financial Times 16 (July 22, 1991). Recognition of the importance of an efficient and liquid resale market for securities that were privately placed in transactions of a substantial size prompted the SEC to adopt Rule 144A, which provides an exemption from registration requirements for certain resales of unregistered securities to institutional investors. 
they vary considerably in their standards for private placements, provision of remedies for fraud, and application of other provisions of their securities laws to private placements. ${ }^{79}$

What, then, is a U.S. court to do if a cross-border private placement results in charges by a disgruntled investor that the issuer made material misrepresentations to induce the investment? Inevitably, the heart of the claim will be section 10(b) of the Securities Exchange Act of 1934.80 Those familiar with section 10 (b) will readily admit that the section has acquired considerable baggage since its adoption. Judicially-developed requirements concerning standing, reliance, causation, materiality, damages, and scienter have each developed significant independent meaning and, taken together, render section 10(b) a uniquely American "antifraud" provision. The issue thus becomes whether section $10(\mathrm{~b})$, with all its embellishments, is the only law of relevance, or whether there may be some room for choice of law.

The traditional approach, reflected in the case law and the Third Restatement of Foreign Relations Law, is to treat the question as one of jurisdiction to prescribe law. If, by virtue of a conduct, effects, or jurisdictional rule-ofreason test, the jurisdiction threshold is crossed, the court will hear the case and apply U.S. securities law, even if the question of whether jurisdiction to prescribe law exists is a "close call." 81 If the jurisdiction threshold is not crossed, the case will be dismissed. Courts do not entertain the possibility of asserting jurisdiction and choosing between foreign or domestic law because securities law is public law and, so the argument goes, courts must apply domestic public law. The judicial assignment, in short, is the all-or-nothing task of determining whether to apply U.S. law or to dismiss the case.

79. In Japan, for example, "public offerings" are subject to a registration requirement if 50 or more investors are solicited. In addition, the exemption for private placements is available only if offerees are sophisticated, institutional investors and acquire the securities for investment purposes only. See generally Yashiki Shimada, A Comparision of Securities Regulation in Japan and the United States, 29 Colum J Transnatl L 319, 332-33 (1991). Under consideration is a reform that would eliminate the numerical limitation in the case of institutional investors. In Mexico, the only requirements applicable to offerings not made through general solicitations are those of honesty and good faith. See Samuel Wolff \& Javier L. Calderon, The Securities Market and Regulation of Mexico, 19 Den J Intl L \& Policy 569, 598 (1991). The securities laws of Switzerland and Taiwan neither define nor regulate private placements. See Lawrence S. Liu, Securities Market Opening Measures: An Analysis, 13 East Asian Exec Reports 9 (Jan 15, 1991); Christian J. Meier-Schatz \& Kim D. Larsen, Switzerland, in Bloomenthal, International Capital Markets at \$ 8D.05[6] (cited in note 69).

80. Securities Exchange Act of 1934, 15 USC § 78j(b) (1988) ("Exchange Act § 10(b)"). See, for example, Zoelsch $v$ Arthur Andersen $\mathcal{E}^{C}$ Co., 824 F2d 27 (DC Cir 1987) (Germans investing in U.S. real estate through a Florida limited partnership); Continental Grain (Australia) Pty., Lid. v Pacific Oilseed, Inc., 592 F2d 409 (8th Cir 1979) (Australian corporation purchasing all of the stock of another Australian corporation from an Australian and two California residents); Leasco Data Processing Equipment Corp. v Maxwell, 468 F2d 1326 (2d Cir 1972) (foreign subsidiary of U.S. corporation purchasing securities of British issuer); Grunenthal $\mathrm{GmbH} v$ Hotz, 712 F2d 421 (9th Cir 1983) (German corporation's purchase of Mexican corporation). Each of these cases represents a dispute unconnected to the operation of organized securities markets and therefore appropriate for a choiceof-law analysis.

81. See AVC Nederland B.V. v Atrium Inv. Partnership, 740 F2d 148, 155 (2d Cir 1984) (jurisdiction to prescribe exists by a "slight margin"). 
The over-inclusive label of "public law" thus renders choice of law irrelevant, but perhaps unnecessarily so. As noted earlier, courts have considerable experience in peering beneath the labels and examining the substance of laws to determine whether they are driven by public interest or compensatory considerations. ${ }^{82}$ Although the Second Restatement of Conflicts recognizes that an action may not be based on a "foreign penal cause of action," it also notes that the proscription is to be interpreted narrowly. ${ }^{83}$ Most foreign states do not subject misrepresentations in private placements to penal law. Many provide private relief for misrepresentations through their civil or commercial codes rather than their securities acts. ${ }^{84}$ Accordingly, the question becomes whether the historical or policy underpinnings of section 10(b) mandate its treatment as public law when applied to private placements. If not, choice of law should be an option.

Violation of section 10 (b) is unlawful. The penal aspect of the section lends support to the argument that it is public law. The Exchange Act itself, however, is strongly oriented towards regulation of the organized securities markets. In citing the necessity for regulation, the Act states that "transactions in securities as commonly conducted upon exchanges and overthe-counter markets are affected with a national public interest which makes it necessary to provide for regulation and control of such transactions." 85 Moreover, there is strong evidence that section 10(b) was designed principally to give the Securities and Exchange Commission plenary power over the markets. ${ }^{86}$ Admittedly, the judicially-developed implied private cause of action has given section 10(b) a life of its own. The section is routinely pleaded in private litigation involving private, face-to-face transactions in which fraud is alleged. In such cases, however, public interest considerations are attenuated, or at least sufficiently so to call into question the status of the section as public rather than private law. Indeed, it is difficult to establish that the public interest is more directly implicated in private securities transactions than it is in contracts involving Japanese trucks, British Steel, or Indonesian rubber. ${ }^{87}$

82. See text accompanying notes 58 to 64 . 64.

83. Restatement (Second) of Conflicts of Laws $\$ 89$ (1971); see text accompanying notes 58 to

84. Indeed, some states do not provide for private causes of action based upon a violation of the securities laws, even if the offerings are public. See, for example, Hiroshi Oda \& R. Geoffrey Grice, Japanese Banking, Securities and Anti-Monopoly Law 105 (Butterworths, 1988) ("Japan does not have any rule similar in scope or effectiveness to the United States anti-security fraud provision embodied in Rule 10b-5. Nor do the Japanese securities laws purport to provide private causes of action to investors for failure to comply with all the technical regulatory requirements established under the Japan Securities and Exchange Law. In essence, therefore, Japanese investors are left to pursue claims in such cases based upon general fraud provisions and gross negligence provisions in the Japanese Civil and Commercial Codes.").

85. Exchange Act, $\& 2$ (emphasis added).

86. See Steve Thel, The Original Conception of section $10(b)$ of the Securities Exchange Act, 42 Stan L Rev 385 (1990).

87. See Richard A. Posner, Economic Analysis of Law 423 (Little, Brown, 3d ed 1986) (arguing that to apply $\$ 10$ (b) to the purchase of an entire business "makes little economic sense" and that the "buyer needs no legal protections beyond those that the common law of fraud gives him"). 
In a number of ways securities law has already been privatized 88 to an extent sufficient to undermine its status as public law. The most obvious example is the dramatic reversal of a long-standing hostility of courts towards arbitration of securities disputes. ${ }^{89}$ Less than forty years ago, Wilko $v$. Swan ${ }^{90}$ held that an agreement to arbitrate could not preclude a defrauded purchaser of securities from seeking a judicial remedy for a violation of section 12(2) of the Securities Act, which establishes an express cause of action based upon misstatements of material fact. At least as a matter of statutory interpretation, the holding was hardly surprising since section 14 of the same act voids stipulations waiving compliance with any provision of the act. Over time, a number of courts extended Wilko to cover the arbitrability of claims under the Exchange Act. ${ }^{91}$ Yet in Scherk $v$. Alberto-Culver Co. ${ }^{92}$ decided twenty years after Wilko, the Court reached quite the opposite conclusion. In Scherk, a disgruntled purchaser sought to sidestep a contract calling for arbitration under Illinois law and pursue section 10(b) claims in federal court. The key distinction between Wilko and Scherk was that the latter case was a complex international transaction for which the applicable governing law was unclear. $^{93}$ The Court reasoned:

Such uncertainty will almost inevitably exist with respect to any contract touching two or more countries, each with its own substantive laws and conflict-of-laws rules. A contractual provision specifying in advance the forum in which disputes shall be litigated and the law to be applied is, therefore, an almost indispensable precondition to achievement of the orderliness and predictability essential to any international business transaction. ...

"The elimination of all such uncertainties by agreeing in advance on a forum acceptable to both parties is an indispensable element in international trade, commerce, and contracting." 94

88. Application of the term "privatize" to describe developments in securities law is not original. See, for example, C. Edward Fletcher, III, Privatizing Securities Disputes Through the Enforcement of Arbitration Agreements, 71 Minn L Rev 393 (1987).

89. Another example is provided by cases involving the definition of a security. See, for example, Reves $v$ Ernst E Young, 494 US 56, 68 (1990) (one factor relevant to the classification of notes as securities is the distribution of the notes to a broad segment of the public); Marine Bank $v$ Weaver, 455 US 551, 559 (1982) ("The unusual instruments found to constitute securities in prior cases involved offers to a number of potential investors, not a private transaction as in this case.").

90.346 US 427 (1953).

91. Although a few decisions suggested that securities claims may be arbitrable when parties to a transaction are sophisticated and have equal bargaining power. See, for example, Alco Standard Corp. $v$ Benalal, 345 F Supp 14, 24 (ED Pa 1972). See generally Fletcher, 71 Minn L Rev at 427-31 (cited in note 88 ).

92. 417 US 506 (1973).

93. As the Scherk Court explained:

Alberto-Culver is an American corporation with its principal place of business and the vast bulk of its activity in this country, while Scherk is a citizen of Germany whose companies were organized under the laws of Germany and Liechtenstein. The negotiations leading to the signing of the contract in Austria and to the closing in Switzerland took place in the United States, England, and Germany . . . . Finally, and most significantly, the subject matter of the contract concerned the sale of business enterprises organized under the laws of and primarily situated in European countries, whose activities were largely, if not entirely, directed to European markets.

Id at 515 .

94. Id at 516, 518 (emphasis added), quoting The Bremen $v$ Zapata Off-Shore Co., 407 US 1, 13-14 (1971). See also $A V C$ Nederland, 740 F2d 148 (upholding an agreement to arbitrate in the 
For a time, Scherk merely established a relatively narrow exception to the bar on arbitration of securities disputes. More recently, however, in Shearson/American Express, Inc. v. McMahon ${ }^{95}$ and Rodriguez de Quijas $v$. Shearson/American Express, Inc., ${ }^{96}$ the Court has come full circle to permit arbitration of claims, under both the Securities Act and the Exchange Act, on the basis of arbitration clauses in standard form contracts between brokers and their clients. Although the decisions in these cases reasoned that enforcement of arbitration agreements does not entail waiver of substantive rights under the securities acts and expressed confidence in the Securities and Exchange Commission's ability to oversee arbitration of securities disputes, they are, as one commentator has observed, radical in their assignment of "disputes that truly implicate core public concerns or involve parties whose bargaining position are fundamentally unequal" to arbitral adjudication. ${ }^{97}$ At the very least, the decisions call into question the long-standing perception of the "public" character of securities laws, and may permit significant privatization of securities law through contracts.

McMahon and Rodriguez blur somewhat the emphasis of Scherk on the importance of developing responses appropriate to the needs of parties contracting in the international arena. One other case with an emphasis similar to Scherk is Mitsubishi Motors Corp. v. Soler Chrysler-Plymouth, Inc., ${ }^{\mathbf{9 8}}$ which considered the enforcement of an agreement to arbitrate a dispute involving asserted violations of United States antitrust laws in Japan. Somewhat surprisingly, the Court did not find the public interest overtones of antitrust laws a sufficient reason to deny enforceability of the agreement to arbitrate.

We are left, then, with . . . the fundamental importance to American democratic ' capitalism of the regime of the antitrust laws. Without doubt, the private cause of action plays a central role in enforcing this regime. ... The treble-damages provision wielded by the private litigant is a chief tool in the antitrust enforcement scheme, posing a crucial deterrent to potential violators.

The importance of the private damages remedy, however, does not compel the conclusion that it may not be sought outside an American court. Notwithstanding its important incidental policing function, the treble-damages cause of action conferred on private parties ... seeks primarily to enable an injured competitor to gain compensation for that injury. ${ }^{99}$

The prospect of arbitrating antitrust disputes in Japan is extraordinary and was not even conceivable as recently as ten or fifteen years ago. Mitsubishi, of course, did not take the final step and sanction application of Japanese law to the dispute and, by implication, even calls into question the Scherk approval of

Netherlands and to apply Dutch law because investor and promoters were Dutch, even though the investment involved the purchase of New York real estate through a Georgia partnership); S.A. Mineracao da Trindade-Samitri v Utah Int'l Inc., 745 F2d 190 (2d Cir 1984) (ordering arbitration of securities claims arising from an international transaction).

95. 482 US 220 (1987).

96. 490 US 477 (1989).

97. Thomas E. Carbonneau, Alternative Dispute Resolution: Melting the Lances and Dismounting the Steeds 136 (U of Illinois Press, 1989) (comments on McMahon but equally applicable to Rodriguez).

98. 473 US 614 (1985).

99. Id at 634-35 (citations omitted and emphasis added). See also McMahon, 482 US at 240 (describing RICO's treble damage provision as serving a "remedial role"). 
choice of law in international agreements. In fact, the applicability of U.S. law in Mitsubishi was conceded by the parties, prompting the Court to note that "in the event the choice-of-forum and choice-of-law clauses operated in tandem as a prospective waiver of a party's right to pursue statutory remedies for antitrust violations, we would have little hesitation in condemning the agreement as against public policy." 100 Mitsubishi thus displays a split personality, at one point assigning the interpretation and enforcement of U.S. antitrust law to Japanese arbitration, while at another proclaiming tersely in dictum that public policy considerations require use of U.S. antitrust law in transnational disputes. Choice-of-law dictum notwithstanding, Mitsubishi represents yet another assault on a rigid application of the public/private distinction, which assigns all matters of economic regulation to the public law category.

The question remains whether Mitsubishi undermines Scherk's sanction of contracting for choice of law. The nature of the disputes in the two cases suggests that it does not. Mitsubishi involved charges that foreign corporations conspired to divide markets in restraint of trade. Scherk, on the other hand, involved claims that express warranties made in furtherance of the sale of businesses had been breached. At least when compared with Mitsubishi, Scherk raises few public interest concerns and is best characterized as a "private" dispute. The absence of public interest considerations and the desirability of permitting parties to contract for certainty regarding the law that will be applied make $S$ cherk, like other cross-border private placements, an appropriate case for privatization of law through contractual choice-of-law provisions.

If choice of law in a cross-border securities transaction is already possible through private ordering, should it also be an option available to courts asked to resolve cross-border securities disputes? One argument against judicial choice-of-law is that judicial resources should not be allocated to complicated choice-of-law questions when the agreement of the parties is silent on the subject. That argument, however, seeks to prove too much. Courts regularly engage in choice-of-law analyses to decide cases inlvolving contract and tort claims; indeed, a good portion of the scholarship of conflict of laws is devoted to this very problem. If securities law is stripped of its public interest overtones in the context of private placements, there is no principled reason why courts should be less inclined to choose law than they are in the myriad of other cases when the agreement of the parties is silent on choice of law.

A second argument against judicial choice of law may be offered by those who believe the U.S. securities laws serve as a model for the world and therefore must represent the "better" law that should be applied by courts. Undeniably, the securities laws of the United States have proven influential abroad. But, as discussed above, ${ }^{101}$ the securities laws serve many functions, ranging from regulating markets and insider trading to providing remedies

100. Mitsubishi, 473 US at 637 n19.

101. See text accompanying notes 52-64. 
for purchasers in private placements of securities. Although section 10(b) itself may be mirrored in a number of foreign laws, judicial refinements of the section (for example, scienter and reliance standards, the implied private cause of action, and damage computation) and its application to private transactions are aspects of securities law that have, at least to date, not significantly influenced foreign law.

A more troubling argument points to the disarray of the conflicts field and the undesirability of extending this "dismal swamp, filled with quaking quagmires," 102 any further. To a significant extent, however, the "swamp" has already been extended by case law and the Third Restatement of Foreign Relations Law, which merely transfer the old wine to new bottles labeled "jurisdiction" rather than "conflicts." Moreover, whether courts adhere to the First Restatement of Conflicts' vested rights analysis, the Second Restatement of Conflicts' "montage of virtually every choice of law theory imaginable,"103 Currie's governmental interests analysis, Leflar's better law approach, or some other methodology, ${ }^{104}$ apparently makes little difference because of a demonstrated preference of courts to apply the law of the forum irrespective of the conflicts approach used. ${ }^{105}$ The problems of indeterminacy arising from conflicting conflicts methodologies and from the supposed uncertainites in the application of particular conflicts approaches, in short, may be overstated. Although a straightforward standard that U.S. law will apply in the absence of contractual provisions to the contrary would send the clearest signal to contracting parties who might desire to avoid application of U.S. law, the likely effect of such a standard would be to shift whatever indeterminacy that may exist from the choice of law analysis to the determination of jurisdiction to prescribe law. ${ }^{106}$

102. William L. Prosser, Interstate Publication, 51 Mich L Rev 959, 971 (1953).

103. Gregory E. Smith, Choice of Law in the United States, 38 Hastings L J 1041, 1170 (1987).

104. U.S. courts may employ as many as ten distinct conflicts methodologies. See Herma Hill Kay, Theory into Practice: Choice of Law in the Courts, 34 Mercer L Rev 521, 585 (1983).

105. A recent empirical study evaluating more than 800 reported decisions concluded that reported decisions following the Second Restatement, interest analysis, or the better-law approachwhich represent three of the four major conflicts methodologies-have reached results that are statistically indistinguishable in favoring forum over foreign law, local over out-of-state parties, and rules of law that are pro-recovery. See Patrick J. Borchers, The Choice-of-Law Revolution: An Empinical Study, 49 Wash \& Lee L Rev 357 (1992). Decisions in the fifteen jurisdictions that still follow the First Restatement-the fourth of the major methodologies-show less of an inclination to apply forum law, favor local litigants, and employ recovery-favoring rules.

106. An opinion by Judge Friendly provides a good illustration of the indeterminacy problem in a jurisdiction analysis. AVC Nederland, 740 F2d 148, arose out of a dispute between a Dutch investor and Dutch promoters of a Georgia partnership formed to invest in New York real estate. The investor alleged fraud and urged the application of $\S 10(\mathrm{~b})$. After noting that any fraud that may have occurred was perpetuated in the Netherlands, Judge Friendly proceeded to determine "subjectmatter jurisdiction" through the balancing analysis outlined in the Restatement (Third) of Foreign Relations Law. Id at 153-54. He observed:

Analyzing the factors we find factors (a)(1) [activity taking place within the regulating state] and possibly (b) [connection between the regulating state and those regulated or protected] pointing in favor of application of $\$ 10(\mathrm{~b})$ and Rule $10 \mathrm{~b}-5$, factors (g) [extent to which another state may have an interest in regulating the activity] and (h) [likelihood of conflict with regulation by other states] against such application, and most of the other factors 
For a number of reasons, courts should have choice-of-law flexibility in private cross-border securities transactions. First, defining the issue as one of determining the extraterritorial application-or spatial reach-of law reflects a monopolistic and narrow view of law that ignores the ease with which capital flows across national boundaries. As a larger and more diverse group of states seek to capture the benefits of cross-border investment, the development of tensions, similar to those in the antitrust arena, will likely be fostered by an approach that views securities regulation through the lens of the extraterritorial application of law.

Second, multistate transactions give rise to conflicts among legal regimes. Moreover, the legal issues raised in private securities transactions are not distinct from the tort and contract issues with which the field of conflict of laws has been dealing for centuries.

Third, capital flows freely across national boundaries; a focus on the extraterritorial application of law gives to those boundaries an importance in investment transactions that they now no longer possess. Finally, in not pursuing the choice-of-law option, courts deny themselves the opportunity to apply the law that best "fits" the dispute, and instead pursue a course of purposeless inflexibility. ${ }^{107}$

inapplicable, dubious or neutral. Under this standard, we think it reasonable, by a rather slight margin, to apply the statute and rule to the facts in this case.

Id at 154-55.

What are we to make of such an analysis used to determine jurisdiction to prescribe law? What weight is accorded (1) the nationality of the promoters, the investors, and the partnership; (2) the fact that the investment concerned New York real estate; and (3) the undefined possibility of conflict with regulation by another state? How is the court to define the interest of Holland in regulating the activity? What is the interest of Holland in regulating fraud in the sale of New York real estate? And why are the other factors outlined in the Third Restatement "inapplicable, dubious or neutral"? Id. Finally, how can a court balance a hodgepodge of unweighted, nebulous factors and conclude that assertion of jurisdiction is reasonable "by a rather slight margin?" Id.

107. The discussion has focused on choice of substantive law to regulate private placement disputes over such matters as the adequacy of disclosure. Other issues that may arise in private placements are closer to the margin of the public/private law distinction. For example, the determination of whether a transaction qualifies as a private placement and therefore is free from whichever filing or registration requirements may apply to public offerings, more closely falls within the province of public law because it reflects legislative and judicial choices concerning such matters as the purposes of regulating public offerings and the class of individuals to whom the protections of regulation should extend.

To illustrate contrasting views on this point, consider the sharply different definitions of public offerings expressed under Australian and U.S. law. Australian courts have defined an offer to the public as one in which anybody who becomes aware of the offer is free to accept it. Accordingly, under Australian law, "an offer which, by its terms, is restricted to a defined group of persons (for example, to all 12,000 employees of the offeror corporation), is not an offer to the public." Hambrook, Australia, in Bloomenthal, International Capital Markets at \$10.04[1] (cited in note 69). Contrast the Australian view with that expressed by the leading U.S. case, SEC v Ralston Purina, 346 US 119 (1953), where the Supreme Court treated a corporation's offering of stock to its own employees as a public offering, and held that the availability of the private placement exemption turns on whether the offerees need the disclosure protections of the Securities Act. Presumably, the offering at issue in Ralston Purina, though unlawful under U.S. law, would not pose problems under Australian law.

Although the definition of a public offering serves as a gateway to the registration provisions of both Australian and American law, and therefore may have the character of public law, choice of the law defining a public offering may prove a desirable option for an offering that spans the two 
Two cases serve to illustrate how choice of law might be used to resolve disputes arising from private securities transactions. In Zoelsch $v$. Arthur Andersen, ${ }^{108}$ German investors brought a section 10(b) action against an American accounting firm based upon an ill-fated investment in an American real estate limited partnership. The limited partnership's investment materials were prepared in the United States and described the real estate investments. The audit report included with the materials was prepared in Germany. The package of investment materials was distributed only to German investors in Germany. Claiming detrimental reliance on false representations and material omissions in the audit report, the German investors initiated litigation in Germany and the United States. The U.S. litigation targeted Arthur Andersen, claiming that the accounting firm had provided misleading information to the German firm preparing the audit. ${ }^{109}$ Conceding insufficient domestic effects to support jurisdiction to prescribe, the investors argued the assertion of such jurisdiction is appropriate because of Arthur Andersen's conduct in the United States.

Zoelsch, like other cases, treated the issue as one of jurisdiction to prescribe law. Describing the case as one in which the "securities transaction occurred abroad," the District of Columbia Circuit rejected the jurisdictional rule of reason now embodied in the Third Restatement of Foreign Relations Law in favor of a conduct test.110 It then defined the threshold for the test as requiring misrepresentations originating in the United States, made with scienter in connection with the purchase or sale of securities, and directly causing the harm to those defrauded. In summary, the court commented: "[W]e believe this test is only a slight recasting, if at all, of the traditional view that jurisdiction will lie in American courts only over proscribed acts done in this country." 111

Zoelsch's casual use of terminology is noteworthy, although hardly exceptional. Whether the "securities transaction occurred abroad" is a matter of considerably more complexity than the court acknowledged. The German investors understood that their funds would be channeled to a Florida limited partnership, which in turn would invest in Tennessee and Georgia real estate.

continents. To deny the courts the choice of law alternative will leave them with the unappealing task of assessing jurisdiction to prescribe law, an exercise that, for the reasons discussed, is ill-suited to an environment in which cross-border securities transactions are common. Perhaps one should treat the U.S. definition of public offerings as public law, not amenable to choice in circumstances where the size of the offering (for example, 12,000 purchasers) is likely to lead to trading in secondary markets by those uninformed by the disclosures that would be prompted by registration necessitates. Using this reasoning, the smaller offering, closer to the margin of U.S. law, may be a more appropriate candidate for choice of law than the larger offering, where trading in secondary markets is likely.

108. 824 F2d 27 (DC Cir 1987).

109. Specifically, the complaint pointed to the following reference in the audit report: "With respect to a number of data and particulars in the prospectus in conjunction with the economic fundamentals we have made inquiries thereabout [of the Memphis branch of Arthur Andersen]." Id at 29.

110. Id at 29-31.

111. Id at 33 . 
The limited partnership prepared written materials in the United States that included descriptions of the investments. The audit materials prepared in Germany referenced inquiries made of Arthur Andersen concerning, under the plaintiff's translation, the "economic fundamentals" or, under the defendant's translation, "the overall environment." 112 The complaint alleged misrepresentations concerning the sufficiency of the limited partnership's capital, the ownership of land by the limited partnership, the status of a lease and the economic viability of a building purchased by the partnership. While it may be possible to assign, loosely speaking, the weight of the fraud to Germany, that determination more appropriately concerns the choice of law to be applied rather than the jurisdiction to prescribe law, particularly when the determination is made, as in Zoelsch, at the summary judgment stage.

In contrast to Zoelsch, some cases take an expansive approach to jurisdiction and thereby resolve a broader range of private investment disputes without regard to foreign law. Consider, for example, Continental Grain (Australia) Pty., Ltd. v. Pacific Oilseeds. ${ }^{113}$ Continental Grain, an Australian corporation wholly owned by a Delaware corporation, purchased all of the stock of Pacific Seeds, another Australian corporation. The selling stockholders, an Australian and two Californians, failed to disclose to the purchaser the intention of Northrup, a Minnesota corporation, to terminate an important contract with Pacific Seeds. Apparently, Northrup cooperated with the sellers and did not advise Continental Grain of its plans. Conduct in the United States included mailings and telephone calls furthering the scheme, transmission of funds to Australia for the closing, and the receipt of funds following the closing. In addition, the sales contract was signed in the United States, and the transaction was closed in Australia. Although it found the domestic effects insufficient to support jurisdiction to prescribe, the Ninth Circuit concluded that the conduct in the United States was sufficiently "significant" to support jurisdiction to prescribe and the application of U.S. securities laws.114 In the court's view, "the fraudulent scheme of nondisclosure was devised and completed in the United States. Then it was 'exported' to Australia."115 The court never considered the relevance of Australian law to a transaction in which one Australian corporation acquired another Australian corporation and which was closed in Australia following negotiations that took place, partly, in Australia.

Zoelsch and Continental Grain are illustrative rather than remarkable, both in their emphasis on the jurisdiction to prescribe rather than the choice of law approach, and in their practical elimination of effects-based jurisdiction in cases not involving securities traded in organized markets. The de facto elimination of the effects-based jurisdiction in private securities transactions, however, is consistent with the treatment of such transactions under private

112. Id at 29.

113. 592 F2d 409 (8th Cir 1979).

114. Id at 420.

115. Id at 421 . 
law amenable to choice of law. Effects remain a basis of jurisdiction to prescribe law when the organized markets are implicated. 16 In these cases, the effects on the markets arguably justify application of domestic "public" law designed to protect the markets. When effects are insufficient to support jurisdiction to prescribe law applicable to private securities transactions, the status of securities law as public law is undermined, and the reasons for not choosing between domestic and foreign law dissipate.

\section{VI}

\section{CONCLUSION}

With remarkable consistency, courts and commentators have defined the problem of domestic regulation of cross-border securities transactions as one of determining limits on the extraterritorial application, or "reach," of domestic "public" law. 117 This article has challenged the prevailing unitary view of the securities acts as public law not amenable to choice of law. The vehicle used for this purpose, the cross-border private placement, serves to illustrate one way in which the securities laws operate as private rather than public law. In the context of cross-border private placements, allowing contractual or judicial choice of law is hardly radical, but instead simply recognizes trends already begun, even if they are not yet fully realized.

A more extended reevaluation of the "public law" character of the securities acts is in order. In Scherk, Mitsubishi, and other cases, ${ }^{118}$ the Supreme Court has stressed the special problems of international transactions, which require the development of approaches generally thought unsuitable for purely domestic transactions. Beyond the sphere of private placements, there is need for a new look at whether areas of securities regulation that undeniably involve public law might also be suitable candidates for at least some degree of choice of law. ${ }^{119}$ In an environment in which no state has the capacity to impose unilaterally on the world its

116. See, for example, SEC v Unifund SAL, 910 F2d 1028 (2d Cir 1990); Schoenbaum v Firstbrook, 405 F2d 200 (2d Cir 1968).

117. The practice of defining the "reach" of domestic public law is not confined to the securities and antitrust cases discussed in this article. Recently, for example, the Supreme Court determined that Title VII does not regulate the employment practices of U.S. companies employing U.S. citizens abroad. See EEOC v Arabian American Oil Co., 111 S Ct 1227 (1991). The majority looked to congressional intent to support its conclusion and did not consider the possibility of conflict with foreign law or customs as relevant to its analysis because Title VII "fails to address conflicts with the laws of other states." Id at 1234. The Court distinguished in this regard the age discrimination statute as legislation in which Congress did address the possibility of such conflicts. Id. See Age Discrimination in Employment Act of 1967, 29 USC $\$ 623(\mathrm{f})(1)$ (1988) (employer may take action prohibited by the act "where such practices involve an employee in a foreign country, and compliance with [the act] would cause such employer . . . to violate the laws of the country in which such workplace is located").

118. See, for example, The Bremen v Zapata Off-Shore Co., 407 US I (1971) (forum selection clause enforceable absent a strong showing that it should be set aside).

119. One such candidate might be the public offering of securities, where something approaching contractual choice of law may be accomplished through prominent disclosures in offering documents of the law to be applied in the event of disputes arising from the offering and the nature of the investor protection provided by that law. 
standards for securities transactions, allowing room for choice of law recognizes the increasing diversity of legal cultures in ways that the reach of law approach does not. 
